\title{
EFEKTIVITAS INTERNAL AUDIT DAN PELAKSANAAN GOOD UNIVERSITY GOVERNANCE PADA PERGURUAN TINGGI
}

\author{
Lia Dahlia Iryani \\ Dosen Tetap Fakultas Ekonomi \\ Universitas Pakuan \\ Selvi Arsanti \\ Dosen Tetap Fakultas Ekonomi \\ Universitas Pakuan
}

\begin{abstract}
ABSTRAK
Tuntutan masyarakat terhadap kualitas pendidikan tinggi saat ini semakin menjadi pacuan bagi setiap institusi pendidikan tinggi meningkatkan mutu akademik beserta pelayanannya. Menyikapi kondisi ini, sudah seyogyanya perguruan tinggi mengembangkan sistem penjaminan mutu dan melakukan pengendalian internal dengan melaksanakan audit mutu akademik.

Penelitian ini dimaksudkan untuk mengetahui efektivitas internal audit pada Perguruan Tinggi, dan pelaksanaan Good University Governace (GUG) pada Perguruan Tinggi. Berdasarkan hasil penelitian, bahwasanya Efektivitas Internal Audit. Tanggapan responden mengenai masing - masing kategori efektivitas internal audit, yaitu independensi sebesar $83 \%$ yang berarti independensi internal audit di perguruan tinggi sudah sangat tinggi, kompetensi sebesar 88,57\% yang berarti kompetensi internal audit di perguruan tinggi sudah sangat baik, kecermatan sebesar $88,8 \%$ yang berarti kecermatan internal audit di perguruan tinggi sudah sangat baik, lingkup pekerjaan sebesar $88,16 \%$ yang berarti lingkup pekerjaan audit internal di perguruan tinggi sudah sangat luas, program audit sebesar $93 \%$ yang berarti program audit internal di perguruan tinggi sudah sangat baik, pelaksanaan audit internal sebesar 92,4\% yang berarti pelaksanaan audit internal di perguruan tinggi sudah sangat baik, laporan audit sebesar 93\% yang berarti laporan hasil audit internal di perguruan tinggi sudah sangat baik, tindak lanjut sebesar 92,67\% yang berarti tindak lanjut atas laporan audit internal di perguruan tinggi sudah sangat baik, dari hasil tersebut dapat disimpulkan bahwa efektivitas internal audit di perguruan tinggi sudah sangat baik dengan nilai sebesar 89,98\%, hal tersebut bisa diperoleh karena perguruan tinggi sudah melaksanakan kedelapan hal tersebut (independensi, kompetensi, kecermatan, lingkup pekerjaan, program audit internal, pelaksanaan audit internal, laporan hasil audit internal, tindak lanjut atas laporan audit) dengan baik. Sedangkan pelaksanaan Good University Governance meliputi 5 prinsip, yaitu: 1) transparansi; 2) independensi; 3) akuntabilitas; 4) responsibilitas; 5) fairness, jawaban responden akan diuraikan berdasarkan masing-masing prinsip, yaitu transparansi sebesar $76 \%$ yang berarti transparansi di perguruan tinggi sudah baik, independensi sebesar 80,67\% yang berarti independensi di perguruan tinggi sudah sangat baik, akuntabilitas sebesar 77,5\% yang berarti akuntabilitas di perguruan tinggi sudah baik, responsibilitas sebesar $81,75 \%$ yang berarti responsibilitas di perguruan tinggi sudah sangat baik, fairness sebesar 79,71\% yang berarti fairness di perguruan tinggi sudah baik. Dari hasil tersebut dapat disimpulkan bahwa
\end{abstract}


pelaksanaan good university governance di perguruan tinggi sudah baik dengan nilai sebesar 78,52 .

Kata kunci: Audit Internal (independensi; kompetensi; kecermatan; lingkup pekerjaan; program audit internal; pelaksanaan audit internal; laporan hasil audit internal; tindak lanjut atas laporan audit), GUG (transparansi, independensi, akuntabilitas, responsibilitas, fairness)

\section{Pendahuluan}

Tuntutan masyarakat terhadap kualitas pendidikan tinggi saat ini semakin menjadi pacuan bagi setiap institusi pendidikan tinggi meningkatkan mutu akademik beserta pelayanannya. Pemerintah juga memperkuat hal ini dengan mengeluarkan berbagai undangundang dan peraturan yaitu Undang-Undang Nomor 20 tahun 2003 tentang sistem pendidikan nasional, Undang-Undang Nomor 14 tahun 2005 tentang Guru dan Dosen, Peraturan Pemerintah Nomor 60 Tahun 2005 tentang perguruan tinggi, Peraturan Pemerintah Nomor 19 tahun 2005 tentang standar pendidikan tinggi, dan Higher Education Long Term Strategy 2003-2010 dan Pedoman Penjaminan Mutu Pendidikan Tinggi tahun 2003. Menyikapi kondisi ini, sudah seyogyanya perguruan tinggi mengembangkan sistem penjaminan mutu dan melakukan pengendalian internal dengan melaksanakan audit mutu akademik. Terkait dengan peningkatan mutu input, proses dan output pendidikan serta pengembangan sistem penjaminan mutu akademik di Perguruan Tinggi, maka diperlukan suatu audit internal bidang akademik. Kegiatan audit internal bidang akademik merupakan salah satu bentuk monitoring dan evaluasi yang dilakukan terhadap capaian maupun target-target yang telah ditetapkan. Kegiatan ini terkait dengan program Renstra lima tahunan terutama pada rencana kerja bidang pendidikan dan kemahasiswaan Perguruan Tinggi pada program kerja peningkatan mutu input, proses dan output pendidikan dan pengembangan sistem penjaminan mutu akademik. Adapun sasaran dari program kerja ini adalah meningkatnya mutu akademik dan adanya penjaminan mutu.

Seiring dengan semakin banyaknya perguruan tinggi, merupakan indikator semakin tinggi kepercayaan masyarakat kepada perguruan tinggi. Oleh karena itu perguruan tinggi harus selalu menjaga kepercayaan masyarakat dengan mengelola secara baik dengan menerapkan Good University Governance $(G U G)$. Agar $G U G$ bisa tercapai perlu adanya peran dari internal audit sebagai konsultan. Sehingga dalam pelaksanaan audit tidak sekedar dituntut menemukan permasalahan dalam PT tersebut namun sekaligus menjadi bagian dari solusi dan memberikan usulan perbaikan untuk PT itu juga. 
Pengawasan yang lemah dari audit internal menyebabkan kurang diterapkannya GCG. Hal ini dapat menimbulkan PT mengeluarkan informasi yang kurang baik terhadap para pengguna. Dari permasalahan-permasalahan tersebut, jika digabungkan ke dalam krisis ekonomi yang melanda Indonesia, maka berakibat PT tersebut tidak akan bertahan lama. Oleh karena itu peran internal audit sangat dibutuhkan untuk mendukung terciptanya Good Corporate Governance.

Internal Auditor memiliki peran penting dalam penerapan Good Corporate Governance (GCG) saat ini. Internal Auditor tidak lagi hanya menjadi sekedar pengawas dan pengontrol yang kehadirannya ditakuti oleh manajemen, tapi sebagai business partner bagi PT. Internal Auditor diharapkan dapat memberikan solusi maksimal terhadap berbagai permasalahan manajemen.

Oleh karena itu, Tujuan Penelitian adalah sebagai berikut: 1) Untuk mengetahui efektivitas internal audit di Perguruan Tinggi; 2) Untuk mengetahui pelaksanaan Good Corporate Governance di Perguruan Tinggi.

\section{Metode Penelitian}

Untuk menjawab rumusan masalah nomor, langkah - langkah yang dilakukan dalam analisis ini, yaitu:

1. Tabulasi jawaban kuesioner

2. Kelompokkan jawaban kuesioner

3. Jumlahkan score masing - masing kelompok jawaban kuesioner

4. Total score secara keseluruhan

5. Bandingkan total score dengan score jawaban maksimum

6. Buat keputusan tentang hasil kuesioner

Untuk mendapatkan gambaran secara menyeluruh tentang persepsi responden atas variabel yang diukur maka dilakukan pengklasifikasian jumlah total skor jawaban responden ke dalam interval skor dengan cara sebagai berikut (Ridwan dan Kuncoro 2008);

1) Nilai indeks minimum $=$ Skor min $\mathrm{x}$ item pernyataan $\mathrm{x}$ jumlah responden

2) Nilai indeks maksimum $=$ Skor maks $x$ item pernyataan $x$ jumlah responden

3) Rentang = Nilai indeks maks - 0

4) Jarak interval = Rentang / jumlah kategori

Untuk menghitung persentase skornya dilakukan dengan cara sebagai berikut:

\section{Jumlah Jawaban \\ Jumlah score maksimum $\mathbf{x} 100 \%$}


Hasil perhitungan kuesioner sehubungan dengan analisis dapat diklasifikasikan secara umum, yaitu:

1. Kriteria penilaian dari hasil kuesioner yang berkaitan dengan "Efektivitas Internal Audit" adalah sebagai berikut:

Klasifikasi Efektivitas Internal Audit

\begin{tabular}{|l|l|}
\hline Persentase & Kriteria \\
\hline $0-20 \%$ & Tidak baik \\
\hline $21-40 \%$ & Kurang baik \\
\hline $41-60 \%$ & Cukup baik \\
\hline $61-80 \%$ & Baik \\
\hline $81-100 \%$ & Sangat baik \\
\hline
\end{tabular}

Sumber: Ridwan dan Kuncoro (2008)

2. Kriteria penilaian dari hasil kuesioner yang berkaitan dengan "pelaksanaan good corporate governance" adalah sebagai berikut:

Klasifikasi Pelaksanaan Good Corporate Governance

\begin{tabular}{|l|l|}
\hline Persentase & Kriteria \\
\hline $0-20 \%$ & Sangat buruk \\
\hline $21-40 \%$ & Buruk \\
\hline $41-60 \%$ & Cukup baik \\
\hline $61-80 \%$ & Baik \\
\hline $81-100 \%$ & Sangat Baik \\
\hline
\end{tabular}

Sumber: Ridwan dan Kuncoro (2008)

\section{Hasil dan Pembahasan}

\subsection{Efektivitas Internal Audit}

Dari ke 8 kategori efektivitas internal audit tersebut yaitu: 1) independensi; 2) kompetensi; 3) kecermatan; 4) lingkup pekerjaan; 5) program audit internal; 6) pelaksanaan audit internal; 7) laporan hasil audit internal; 8) tindak lanjut atas laporan audit.

Dari perhitungan penulis, tanggapan responden mengenai masing - masing kategori efektivitas internal audit, yaitu independensi sebesar $83 \%$ yang berarti independensi internal audit di perguruan tinggi sudah sangat tinggi, kompetensi sebesar 88,57\% yang berarti kompetensi internal audit di perguruan tinggi sudah sangat baik, kecermatan sebesar 88,8\% yang berarti kecermatan internal audit di perguruan tinggi sudah sangat baik, lingkup 
pekerjaan sebesar $88,16 \%$ yang berarti lingkup pekerjaan audit internal di perguruan tinggi sudah sangat luas, program audit sebesar 93\% yang berarti program audit internal di perguruan tinggi sudah sangat baik, pelaksanaan audit internal sebesar 92,4\% yang berarti pelaksanaan audit internal di perguruan tinggi sudah sangat baik, laporan audit sebesar 93\% yang berarti laporan hasil audit internal di perguruan tinggi sudah sangat baik, tindak lanjut sebesar 92,67\% yang berarti tindak lanjut atas laporan audit internal di peguruan tinggi sudah sangat baik.

\subsection{Pelaksanaan Good University Governance}

Pelaksanaan Good University Governance meliputi 5 prinsip, yaitu: 1) transparansi; 2) independensi; 3) akuntabilitas; 4) responsibilitas; 5) fairness. Jawaban responden akan diuraikan berdasarkan masing-masing prinsip.

Berdasarkan perhitungan, tanggapan responden mengenai masing - masing prinsip GUG, yaitu transparansi sebesar $76 \%$ yang berarti transparansi di perguruan tinggi sudah baik, independensi sebesar 80,67\% yang berarti independensi di perguruan tinggi sudah sangat baik, akuntabilitas sebesar 77,5\% yang berarti akuntabilitas di perguruan tinggi sudah baik, responsibilitas sebesar $81,75 \%$ yang berarti responsibilitas di perguruan tinggi sudah sangat baik, fairness sebesar 79,71\% yang berarti fairness di perguruan tinggi sudah baik.

\section{Kesimpulan}

Penelitian ini untuk mengetahui bagaimana efektifitas internal audit dan pelaksanaan GUG pada beberapa perguruan tinggi di Kota Bogor. Responden yang ada sebanyak 20 responden dari bagian audit internal dan bagian compliance. Berdasarkan hasil penelitian yang telah dijelaskan pada bab sebelumnya, dapat disimpulkan bahwa:

1. peran internal audit di perguruan tinggi sudah sangat baik hal tersebut terlihat dengan independensi yang ada karena bagian audit internal di perguruan tinggi adalah orang orang yang tidak terlibat dalam kegiatan operasional PT tersebut. Auditor internal yang ada di perguruan tinggipun adalah orang - orang yang memiliki latar belakang dan pendidikan yang memadai. Bagian audit internal di perguruan tinggi sudah melaksanakan tanggung jawabnya dengan baik, dengan adanya program audit untuk pedoman dalam melakukan audit, adanya laporan hasil audit yang menjelaskan permasalahan atau temuan-temuan audit serta saran dan rekomendasi, adanya tidak 
lanjut oleh auditor berupa pemantauan untuk memastikan tindakan perbaikan telah dilakukan oleh perguruan tinggi.

2. pelaksanaan good university governance di perguruan tinggi sudah terlaksana dengan baik hal tersebut dilihat dengan transparansi yang dilakukan oleh perguruan tinggi. Prinsip transparansi telah dilaksanakan dengan baik karena perguruan tinggi sudah menyampaikan informasi kepada pihak-pihak yang terkait, selalu menyediakan laporan keuangan dan laporan manajemen secara berkala sehingga dapat diketahui bahwa perguruan tinggi telah melakukan transparansi terhadap hal-hal yang dianggap material untuk disampaikan kepada stakeholders. independensi di perguruan tinggi telah dilaksanakan dengan sangat baik karena adanya penetapan setiap fungsi dalam perguruan tinggi yang sesuai dengan hukum yang berlaku terlihat dari kebijakankebijakan yang telah ditetapkan oleh perguruan tinggi tidak bertentangan dengan hukum yang berlaku. Responsibilitas perguruan tinggi sudah berjalan baik karena pengelolaan di PT sudah sesuai dengan bisnis yang sehat, secara konsisten mengelola PT dengan baik untuk meningkatkan citranya untuk tetap bertahan dalam kegiatannya. Pertanggungjawaban di perguruan tinggi tidak hanya pada peraturan dan undangundang yang berlaku tetapi juga masyarakat. Seiring dengan efektifitas internal audit di perguruan tinggi yang sudah baik, maka pelaksanaan good university governance di pergurua tinggipun dapat terwujud dengan baik.

\section{Daftar Pustaka}

Arens, Alvin.A dan James K loebecke. 2009. Auditing and Assurance Service, Jakarta: Salemba Empat.

Forum for Corporate Governance in Indonesia (FGCI), 2001, Peranan Dewan Komisaris dan Komite Audit dalam Pelaksanaan Corporate Governance, Jakarta: Forum for Corporate Governance in Indonesia

Gusnardi, “Analisis Faktor Audit Internal dan Pengaruhnya Terhadap Pelaksanaan Good Corporate Governance”, Jurnal Ekuitas, Vol. 12 ( No. 3), September 2008.

Jaafar, Redwan dan Sumiyati, 2008, Kode Etik dan Standar Audit, Edisi Kelima, Jakarta: Pusat Pendidikan dan Pelatihan Pengawasan Badan Pengawasan Keuangan dan Pembangunan.

Komite Nasional Kebijakan Corporate Governance. 2004. Pedoman Good Corporate Governance Perbankan Indonesia. 
Mulyadi, 2008, Auditing, Edisi 6, Jakarta: Salemba Empat.

Sawyer, Lawrence B, Mortimer A. Dittenhofer dan James H. Scheiner. 2005. Audit Internal, Edisi 5, Jakarta: Salemba Empat.

Sugiyono, 2002, Metode Penelitian Bisnis, Bandung: alfabeta

Tampubolon, Ridwan, 2005, Audit Intern Berbasis Risiko, Jakarta: PT. Elex Media Komputindo.

Tugiman, Hiro, 2006, Standar Profesional Audit Internal, Yogyakarta: Kanisius.

Tunggal, Amin Widjaja, 2010, Principles of Internal Auditing, Harvarindo.

Yayasan Pendidikan Internal Audit (YPIA), 2007, Dasar - Dasar Audit Internal Sektor Publik, Tangerang: Sekolah Tinggi Akuntansi Negara. 